\title{
Identifikasi Angin Silang (Cross Wind) di Sekitar New Yogyakarta International Airport Memakai Plot Wind Rose
}

\author{
Fatkhuroyan $^{1}$, Bambang Wijayanto ${ }^{2}$ \\ ${ }^{1}$ Pusat Penelitian dan Pengembangan BMKG, J1. Angkasa 1No.2 Kemayoran Jakarta 10720 \\ ${ }^{2}$ Pusat Meteorologi Penerbangan BMKG, Jl. Angkasa 1No.2 Kemayoran Jakarta 10720
}

Email : izzaroyan@yahoo.com

\begin{abstract}
Wind has important role in aviation safety. The aim of the research is to analyze monthly wind profile and crosswind potential in the area of New Yogyakarta International Airport. The method used by installing 4 (four) AWS (Automatic Weather Station) at the end and the middle of the runway during March to September 2017. The results show that the wind patterns in the March-May period have varying directions with an average speed of 5-8 knots. In June - September, the wind pattern blows from the East - Southeast direction with an average speed of 6-9 knots. The maximum wind speed occurred between 14-20 knots and no crosswind potential was found for the runway length of 3,600 meters.
\end{abstract}

Keywords: Crosswind, AWS, Knot.

Abstrak: Angin merupakan unsur cuaca yang sangat penting dalam keselamatan penerbangan. Penelitian ini bertujuan melakukan analisa profil angin bulanan dan potensi terjadinya Crosswind pada area New Yogyakarta International Airport. Metode yang dipakai dengan memasang 4 (empat)buah AWS (Automatic Weather Station) di ujung dan tengah landasan selama bulan Maret hingga September 2017. Hasil pengamatan dan analisa menunjukan bahwa pola angin pada periode Maret - Mei memiliki arah yang bervariasi dengan kecepatan rata-rata $5-8$ knot. Pada Juni - September, pola angin berhembus dari arah Timur - Tenggara dengan kecepatan rata-rata 6 - 9 knot. Selama periode pengamatan, kecepatan angin maksimum yang terjadi antara $14-20$ knot dan tidak ditemukan potensi terjadinya cross wind untuk panjang landasan 3.600 meter.

Kata kunci: Crosswind, AWS, Knot.

\section{PENDAHULUAN}

Peran cuaca dalam penerbangan sangat besar serta informasi cuaca mempunyai andil dalam peningkatan efisiensi dan efektivitas kegiatan dan keselamatan penerbangan (Page, 2010). selain itu cuaca mempunyai potensi yang membahayakan harta dan jiwa (Gerz, 2014). Namun demikian tidak mudah untuk mengatakan cuaca yang mana yang membahayakan, karena dampak cuaca bergantung pula kepada faktor lain.

Khususnya dalam penerbangan, selain kadar atau intensitas unsur cuaca, jenis pesawat, kondisi pesawat, dan posisi penerbangan juga faktor yang menentukan sensitifitasnya terhadap cuaca. Misalnya angin silang (cross wind) di landasan terbang yang berkecepatan 20 knot, mungkin dapat menimbulkan bahaya bagi pesawat kecil yang melakukan pendaratan, tetapi tidak ada pengaruhnya bagi pesawat besar dan modern (FAA, 2014).

Namun demikian, karena setiap pesawat terbang mempunyai tiga kegiatan yang sama, yakni lepas landas, terbang, dan mendarat, maka penggunaan arti bahaya dalam penerbangan umumnya diterapkan untuk masing-masing kegiatan tersebut (Fadholi, 2012).

Menurut ICAO (ICAO Annex 14, 2009), Komponen cross wind yang dapat menghalangi take-off dan landing pesawat udara pada umumnya yaitu ketika kecepatannya melebihi:

1. $37 \mathrm{~km} / \mathrm{jam}$ (20 knot) untuk pesawat dengan ARFL (Aeroplane Reference Field Lenghth)

1.500 meter atau lebih, kecuali jika tindakan pengereman pada landasan pacu buruk 
(dikarenakan koefisien gesek longitudinal yang tidak mencukupi), maka komponen cross wind lebih dari $24 \mathrm{~km} / \mathrm{jam}$ (13 knot) dapat menghalangi takeoff dan landing pesawat;

2. $24 \mathrm{~km} / \mathrm{jam}(13 \mathrm{knot})$ untuk pesawat dengan ARFL (Aeroplane Reference Field Lenghth) 1.200 meter sampai $<1.500$ meter;

3. $19 \mathrm{~km} / \mathrm{jam}(10 \mathrm{knot})$ untuk pesawat dengan ARFL (Aeroplane Reference Field Lenghth) < 1.200 meter.

Tujuan penelitian ialah untuk mengidentifikasi potensi terjadinya cross wind pada area calon New Yogyakarta International Airport.

\section{DATA DAN METODOLOGI}

Data yang digunakan dalam penelitian ini merupakan data arah dan kecepatan angin permukaan yang dihasilkan dari pengamatan 4 (empat) buah AWS (Automatic Weather Station) per 10 menit. 2 (dua) titik berada di ujung landasan dan 2 (dua) titik berada di tengah landasan. Hal ini guna mengetahui arah dan kecepatan angin di masing-masing ujung landasan dan tengah landasan.

Dilihat dari topografi, penempatan 2 (dua) titik AWS yang berada di sebelah selatan rencana pembangunan runway, kondisinya berhadapan langsung dengan laut selatan. Sedangkan 2 (dua) titik AWS lainnya berada di sebelah utara runway dengan kondisi banyak tanaman dan lahan perkebunan. Sehingga pengaruh angin darat dan angin laut cukup kuat pada area survei.

Data tersebut merupakan data hasil pengamatan selama kurun waktu Maret hingga September 2017. Bulan Maret - April dipengaruhi oleh angin muson barat, sedangkan bulan Mei, Juni, Juli, Agustus dipengaruhi oleh angin muson timur. Untuk rutinitas take off dan landing suatu pesawat, cross wind merupakan komponen yang paling penting karena paling sering terjadi pada waktu tertentu.

Masing-masing titik pengamatan AWS tersebut berada pada posisi koordinat (seperti ditunjukkan pada Tabel 1. dan Gambar 1).

Tabel 1. Posisi Koordinat AWS

\begin{tabular}{lll}
\hline No & Lintang & Bujur \\
\hline AWS 1 & $7.898980^{\circ} \mathrm{LS}$ & $110.042530^{\circ} \mathrm{BT}$ \\
AWS 2 & $7.906300^{\circ} \mathrm{LS}$ & $110.055400^{\circ} \mathrm{BT}$ \\
AWS 3 & $7.902420^{0} \mathrm{LS}$ & $110.057430^{\circ} \mathrm{BT}$ \\
AWS 4 & $7.910850^{\circ} \mathrm{LS}$ & $110.072650^{\circ} \mathrm{BT}$ \\
\hline & \multicolumn{1}{c}{ Sumber: BMKG } \\
\hline & & \\
\hline
\end{tabular}

Gambar 1. Letak AWS untuk pengamatan. Sumber: $B M K G$

Data yang telah terkumpul kemudian dilakukan pengolahan dan perhitungan untuk mendapatkan nilai-nilai komponen kecepatan angin. Dalam proses pengolahan data, digunakan dua metode. Metode pertama adalah metode windrose untuk meninjau dominasi angin (Fadholi, 
2013). Perangkat lunak yang digunakan untuk mem-plot diagram windrose adalah WR Plot versi 7.1 yang merupakan perangkat lunak open source (WRPlot, 2016).

Metode kedua dilakukan dengan menguraikan vektor angin dalam komponen arah U (headwind/tailwind) dan V (crosswind). Angin tersebut berasal dari hembusan di permukaan runway. Komponen vektor angin yang dikategorikan signifikan memiliki besar lebih dari 7 knot (Fadholi, 2013). Perhitungan komponen angin tersebut dilakukan dengan persamaan (1) dan (2) sebagai berikut (FAA, 2000; ICAO, 2011).

Angin searah

$U=f f * \cos (R W-W D)$

Angin menyilang

$V=f f * \sin (R W-W D)$

Keterangan :

$\mathrm{U}=$ Kecepatan headwind/tailwind (knot),bernilai positif untuk angin dari belakang dan bernilai negatif untuk angin dari depan.

$\mathrm{V}=$ Kecepatan crosswind (knot), bernilai positif untuk angin dari kiri dan bernilai negatif untuk angin dari kanan.

$\mathrm{ff}=$ Kecepatan angina (knot)

$\mathrm{RW}=$ Arah Runway

$\mathrm{WD}=$ Arah Angin.

Hampir seluruh maskapai penerbangan komersial di Indonesia banyak menggunakan tipe Boeing 737 (B737) dan ada beberapa yang menggunakan tipe Airbus 320 (A320). Tipe B737 mempunyai batas maksimum menerima komponen crosswind antara 31 knot sampai 36 knot bervariasi pada setiap serinya (Boeing, 1999).

Sedangkan untuk perencanan pengembangan dan pembangunan tahap I, II, dan III bandar udara New Yogyakarta International Airport akan mampu didarati tipe Boeing 747-400 dengan panjang runway hingga mencapai 3600 (tiga ribu enam ratus) meter (KepMenhub No. 1164 Tahun 2013).

\section{HASIL DAN PEMBAHASAN}

Data yang diolah untuk masing-masing titik AWS adalah 4310 data arah dan kecepatan angin. Data tersebut kemudian diolah dan disaring sesuai ketentuan ICAO (ICAO Annex 14, 2009), sehingga diperoleh data-data angin yang diduga berpotensi cross wind. Pengolahan dan analisa dilakukan perbulan guna mengetahui kondisi klimatologis angin tiap bulannya yang dipengaruhi oleh angin muson barat dan muson timur serta angin laut dan angin darat selama periode pengamatan.

\subsection{Analisis Windrose bulan Maret}

Kondisi arah angin sesaat pada bulan Maret 2017 menunjukan pola arah angin yang bervariasi antara Barat Laut hingga Barat Daya pada empat titik pengamatan. Hal ini menunjukan bahwa angin muson barat masih berpengaruh terhadap kondisi selama pengamatan. Untuk site 1 dan 2, kecepatan angin antara 10-13 knot sekitar 2\%, kecepatan 710 knot memiliki persentasi sekitar $4 \%$. Pada site 3 dan 4, kecepatan angin pada umumnya di bawah 7 knot. Kecepatan angin rata-rata selama Maret 2017 sekitar 4 knot dengan presentase angin calm dari empat titik pengamatan antara 3 hingga 8\%. Grafik windrose bulan Maret 2017 dapat dilihat pada Gambar 2. 


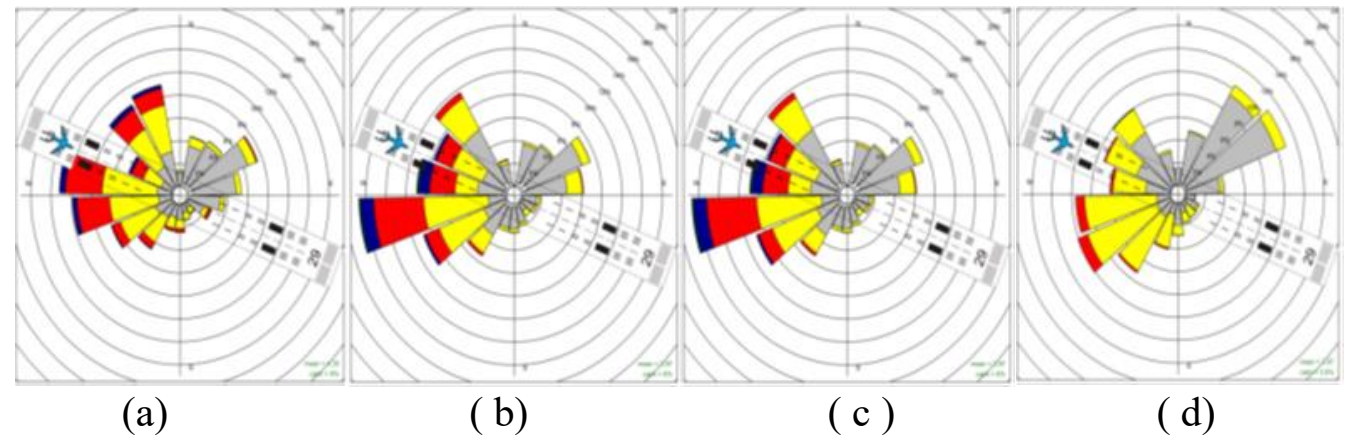

Gambar 2. Grafik Windrose Angin Maret 2017 (a) site 1 (b) site 2 (c) site 3 (d) site 4

\subsection{Analisis Angin Crosswind bulan Maret}

Dari hasil perhitungan menggunakan formula diperoleh bahwa pada Maret 2017, potensi terjadinya angin Crosswind $>10$ knot hanya terjadi di site 1 sebanyak 2 kali kejadian, dan site 2 sebanyak 1 kali kejadian, seperti Tabel 2.

Tabel 2a. Perhitungan Crosswind dan Tailwind Site 1

\begin{tabular}{llllll}
\hline Tgl & Jam & WS & WD & XW & HW/TW \\
\hline 11 & 08.31 & 15.9 & 220.9 & 14.9 & 5.7 \\
19 & 14.07 & 15.8 & 321.8 & -8.3 & 13.4 \\
20 & 10.06 & 16.5 & 259.9 & 8.3 & 14.3 \\
20 & 12.14 & 16.2 & 281.8 & 2.3 & 16.0 \\
25 & 23.12 & 16.8 & 250.4 & 10.7 & 12.9
\end{tabular}

Tabel 2c. Perhitungan Crosswind dan Tailwind Site 3

\begin{tabular}{llllll}
\hline Tgl & Jam & WS & WD & XW & HW/TW \\
\hline 10 & 03.39 & 5.3 & 220.6 & 5.0 & 1.9 \\
\hline 10 & 03.42 & 4.5 & 225.7 & 4.1 & 3.8
\end{tabular}

Tabel 2b. Perhitungan Crosswind dan Tailwind Site 2

\begin{tabular}{llllll}
\hline Tgl & Jam & WS & WD & XW & HW/TW \\
\hline 13 & 23.05 & 18.8 & 277.5 & 4.1 & 18.4 \\
20 & 10.04 & 19.5 & 252.2 & 12.0 & 15.4 \\
20 & 12.18 & 20.1 & 283.4 & 2.3 & 20.0 \\
21 & 10.55 & 18.0 & 269.3 & 6.4 & 16.9 \\
\hline
\end{tabular}

Tabel 2d. Perhitungan Crosswind dan Tailwind Site 4

\begin{tabular}{llllll}
\hline Tgl & Jam & WS & WD & XW & HW/TW \\
\hline 10 & 03.39 & 4.1 & 205.6 & 4.1 & 0.4 \\
10 & 03.42 & 4.6 & 217.4 & 4.4 & 1.4 \\
\hline
\end{tabular}

Ket :

WS $=$ Wind Speed

$\mathrm{WD}=$ Wind Direction

$\mathrm{XW}=$ Cross Wind

HW $=$ Head Wind (Jika Nilai Positif)

TW $=$ Tail Wind (Jika Nilai Negatif)

\subsection{Analisis Windrose bulan April}

Kondisi arah angin pada bulan April 2017 menunjukan pola arah angin yang sangat bervariasi. Tidak ada arah angin dominan dari setiap titik pengamatan pada bulan April. Hal ini disebabkan karena pada bulan April mengalami musim transisi dari musim baratan ke musim timuran. Kecepatan angin rata-rata selama April sekitar 3 Knot dengan persentasi angin calm 
sekitar 10\% (site 1-3) sedangkan persentasi angin calm terendah terdapat di site 4 (3.5\%). Grafik windrose bulan April 2017 dapat dilihat pada Gambar 3.

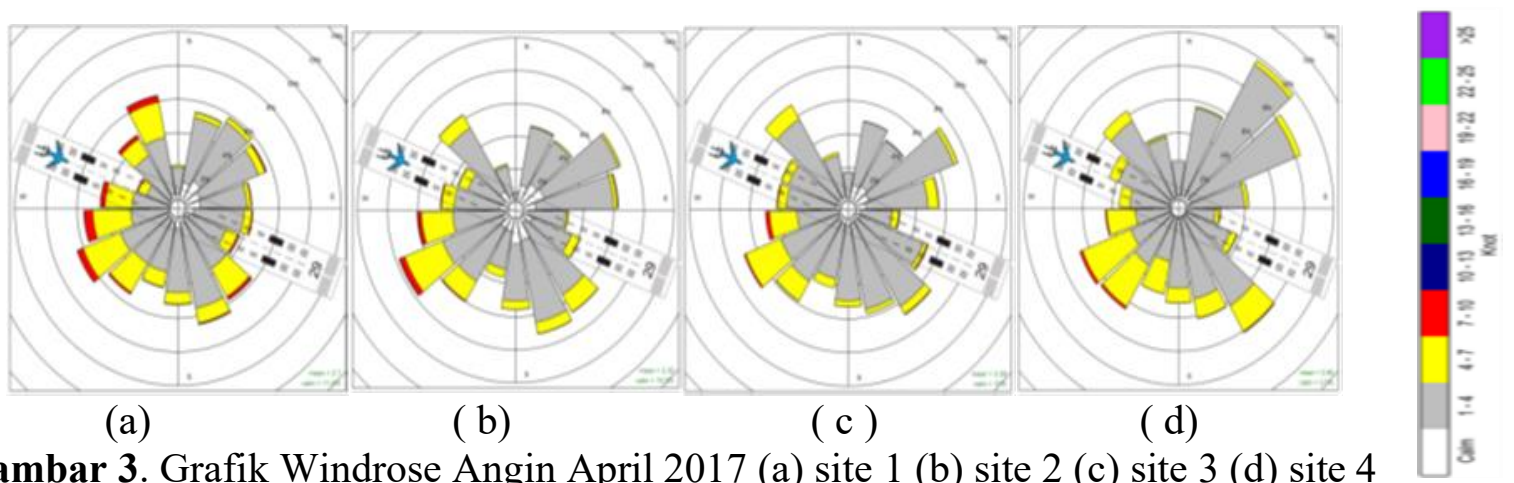

Gambar 3. Grafik Windrose Angin April 2017 (a) site 1 (b) site 2 (c) site 3 (d) site 4

\subsection{Analisis Angin Crosswind bulan April}

Dari hasil perhitungan menggunakan formula diperoleh bahwa pada April 2017, potensi terjadinya angin Crosswind $>10$ knot hanya terjadi di site 1 sebanyak 2 kali kejadian, dan site 2 sebanyak 1 kali kejadian. Sedangkan site 4, terjadi cross wind sebanyak 2 kali dengan kecepatan sebesar 7 hingga 8 knot, seperti Tabel 3.

Tabel 3a. Perhitungan Crosswind dan Tailwind Site 1

\begin{tabular}{llllll}
\hline Tgl & Jam & WS & WD & XW & HW/TW \\
\hline 2 & 15.22 & 14.3 & 156.1 & 10.3 & 9.9 \\
\hline 2 & 15.33 & 13.3 & 153.9 & 9.2 & 9.6 \\
\hline 4 & 14.09 & 13.8 & 132.5 & 5.3 & 12.7 \\
\hline 25 & 08.25 & 13.4 & 53.1 & 11.2 & 7.3 \\
\hline
\end{tabular}

Tabel 3c. Perhitungan Crosswind dan Tailwind Site 3

\begin{tabular}{llllll}
\hline Tgl & Jam & WS & WD & XW & HW/TW \\
\hline 3 & 09.25 & 11.7 & 309.3 & 3.9 & 11.0 \\
30 & 13.35 & 12 & 89.9 & 4.1 & 11.3 \\
\hline
\end{tabular}

Tabel 3b. Perhitungan Crosswind dan Tailwind Site 2

\begin{tabular}{llllll}
\hline Tgl & Jam & WS & WD & XW & HW/TW \\
\hline 2 & 12.57 & 13.6 & 89.3 & 4.8 & 12.7 \\
\hline 2 & 15.24 & 14.3 & 152 & 9.6 & 10.6 \\
\hline 3 & 09.26 & 15.6 & 334.4 & 10.9 & 11.1 \\
\hline
\end{tabular}

Tabel 3d. Perhitungan Crosswind dan Tailwind Site 4

\begin{tabular}{llllll}
\hline Tgl & Jam & WS & WD & XW & HW/TW \\
\hline 2 & 15.18 & 10.9 & 151.4 & 7.2 & 8.2 \\
2 & 15.24 & 13.3 & 149.9 & 8.5 & 10.2 \\
\hline
\end{tabular}

\subsection{Analisis Windrose bulan Mei}

Kondisi arah angin dari keempat titik pengamatan pada bulan Mei 2017 menunjukan pola arah angin yang didominasi oleh angin Tenggara. Hal ini menunjukan pada bulan Mei telah memasuki musim kemarau dengan adanya angin muson timur. Kecepatan angin maksimum terjadi di site 1 pada tanggal 1 Mei 2017 Pukul Pukul 18.15 WIB sebesar 12.9 knot. Kecepatan angin rata-rata selama bulan Mei 2017 sekitar 2 hingga 3 Knot dengan presentase angin calm berkisar antara 11 hingga 13\% (site 1, 2 dan 3) sedangkan presentase angin calm terendah tercatat di site 4 (3\%). Pada site 1, 3 dan 4, kecepatan angin antara 7-10 knot sekitar $2 \%$. Grafik windrose bulan Mei 2017 dapat dilihat pada Gambar 4. 


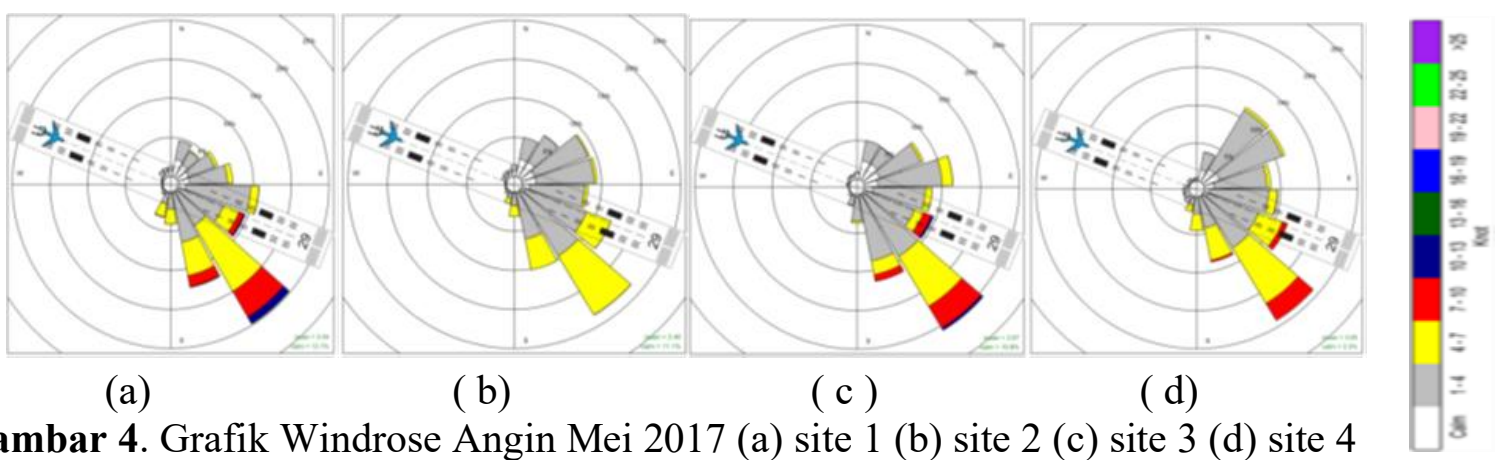

Gambar 4. Grafik Windrose Angin Mei 2017 (a) site 1 (b) site 2 (c) site 3 (d) site 4

\subsection{Analisis Angin Crosswind bulan Mei}

Dari hasil perhitungan menggunakan formula diperoleh hasil bahwa pada Mei 2017 tidak ditemukan potensi crosswind. Hasil perhitungan dapat dilihat pada Tabel 4.

Tabel 4a. Perhitungan Crosswind dan Tailwind Site 1

Tabel 4b. Perhitungan Crosswind dan Tailwind Site 2

\begin{tabular}{llllll}
\hline Tgl & Jam & WS & WD & XW & HW/TW \\
\hline 1 & 09.59 & 12.1 & 140.5 & 6.1 & 10.4 \\
1 & 10.26 & 12.7 & 129.4 & 4.2 & 12.0 \\
1 & 11.15 & 12.9 & 134.4 & 5.3 & 11.7 \\
\hline
\end{tabular}

\begin{tabular}{llllll}
\hline Tgl & Jam & WS & WD & XW & HW/TW \\
\hline 1 & 06.29 & 7.6 & 145.3 & 4.4 & 6.2 \\
1 & 07.16 & 7.7 & 144.1 & 4.3 & 6.4 \\
\hline
\end{tabular}

Tabel 4c. Perhitungan Crosswind dan Tailwind Site 3

Tabel 4d. Perhitungan Crosswind dan Tailwind Site 4

\begin{tabular}{llllll}
\hline Tgl & Jam & WS & WD & XW & HW/TW \\
\hline 1 & 07.09 & 11.5 & 132.1 & 4.3 & 10.7 \\
3 & 10.27 & 12.1 & 134.6 & 5.0 & 11.0 \\
\hline
\end{tabular}

\begin{tabular}{llllll}
\hline Tgl & Jam & WS & WD & XW & HW/TW \\
\hline 1 & 06.32 & 9.2 & 148.5 & 5.7 & 7.2 \\
1 & 07.23 & 9.5 & 139 & 4.6 & 8.3 \\
1 & 09.07 & 9.9 & 134.7 & 4.1 & 9.0 \\
\hline
\end{tabular}

\subsection{Analisis Windrose bulan Juni}

Arah angin dari keempat titik pengamatan pada bulan Juni 2017 masih didominasi oleh angin tenggara dengan kecepatan angin maksimum terjadi di site 3 pada tanggal 25 Juni 2017 Pukul 17.40 WIB sebesar 8.7 knot. Angin muson timur sangat berpengaruh pada bulan ini. Kecepatan angin rata-rata selama bulan Juni 2017 sekitar 3 knot dengan presentase angin calm sekitar 8\% (site 1, 2, dan 3) sedangkan presentase angin calm terendah tercatat di site 4 (3\%). Pada site 3, tercatat kecepatan angina 7-10 knot sebesar $2 \%$. Grafik windrose bulan Juni 2017 dapat dilihat Gambar 5. 


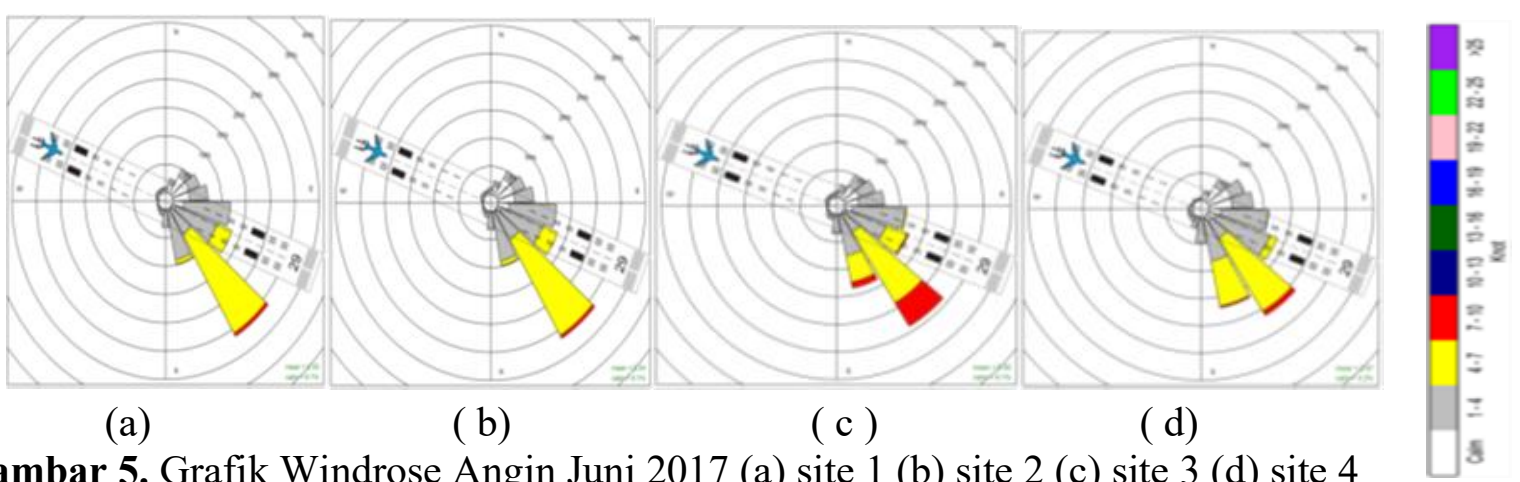

Gambar 5. Grafik Windrose Angin Juni 2017 (a) site 1 (b) site 2 (c) site 3 (d) site 4

\subsection{Analisis Angin Crosswind bulan Juni}

Dari hasil perhitungan menggunakan formula diperoleh hasil bahwa pada Juni 2017 tidak ditemukan potensi crosswind. Hasil perhitungan dapat dilihat pada Tabel 5.

Tabel 5a. Perhitungan Crosswind dan Tailwind Site 1

\begin{tabular}{llllll}
\hline Tgl & Jam & WS & WD & XW & HW/TW \\
\hline 1 & 07.30 & 7.5 & 140.7 & 3.8 & 6.4 \\
17 & 02.30 & 7.5 & 141.8 & 4.0 & 6.4 \\
17 & 03.30 & 7.6 & 143.2 & 4.2 & 6.4 \\
\hline
\end{tabular}

Tabel 5c. Perhitungan Crosswind dan Tailwind Site 3

\begin{tabular}{llllll}
\hline Tgl & Jam & WS & WD & XW & HW/TW \\
\hline 1 & 07.30 & 8.5 & 160.2 & 6.6 & 5.5 \\
17 & 02.50 & 8.6 & 141.8 & 4.5 & 7.3 \\
25 & 07.30 & 8.6 & 142.2 & 4.6 & 7.3 \\
\hline
\end{tabular}

Tabel 5b. Perhitungan Crosswind dan Tailwind Site 2

\begin{tabular}{llllll}
\hline Tgl & Jam & WS & WD & XW & HW/TW \\
\hline 25 & 06.50 & 7.5 & 138.7 & 3.6 & 6.6 \\
25 & 07.30 & 7.4 & 139.3 & 3.6 & 6.5 \\
\hline
\end{tabular}

Tabel 5d. Perhitungan Crosswind dan Tailwind Site 4

\begin{tabular}{llllll}
\hline Tgl & Jam & WS & WD & XW & HW/TW \\
\hline 1 & 07.30 & 7.8 & 146.7 & 4.7 & 6.3 \\
25 & 06.50 & 7.8 & 145.9 & 4.6 & 6.3 \\
25 & 07.30 & 7.7 & 148.9 & 4.9 & 6.0 \\
\hline
\end{tabular}

\subsection{Analisis Windrose bulan Juli}

Arah angin dari keempat titik pengamatan pada bulan Juli 2017 didominasi oleh angin dari Tenggara dengan kecepatan angin maksimum terjadi di site 1 dan 2 mencapai 16 knot sekitar 1 $\%$. Angin muson timur sangat berpengaruh pada bulan ini. Di kedua site tersebut juga menunjukan persentasi kecepatan angin 10-13 knot sekitar $4 \%$ dan persentasi kecepatan angin 7-10 knot sekitar $6 \%$. Sedangkan site 3, umumnya kecepatan angin 4-7 knot sekitar $8 \%$ dari arah tenggara. Pada site 4, kecepatan angina 4-7 knot sekitar 8\% dan 7-10 knot sekitar $4 \%$ juga dari Tenggara. Grafik windrose bulan Juli 2017 dapat dilihat pada Gambar 6. 


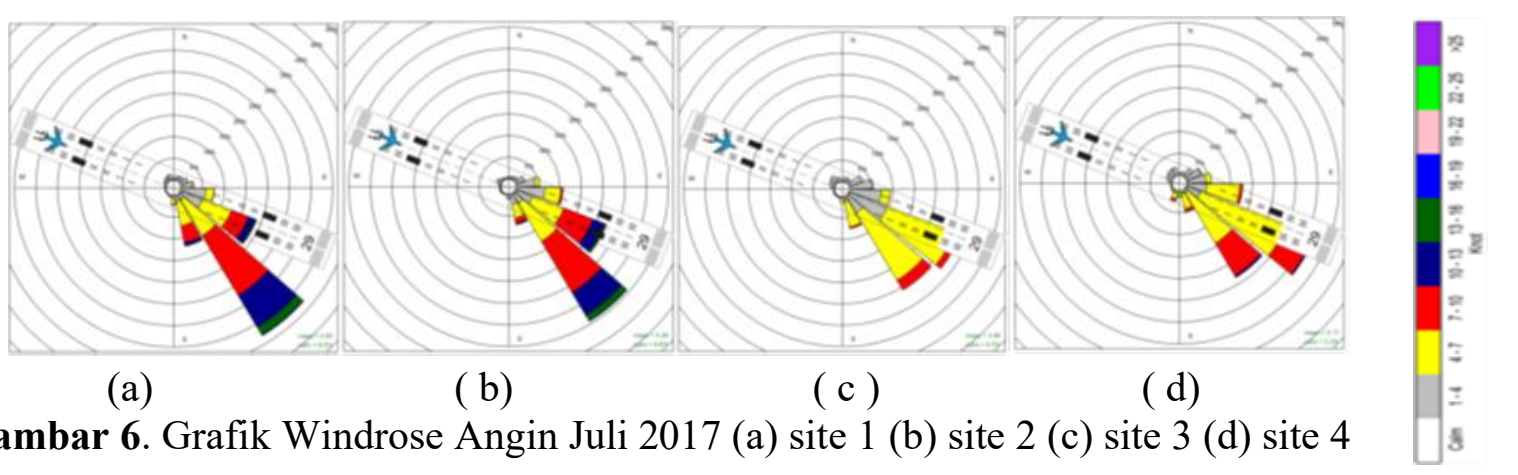

Gambar 6. Grafik Windrose Angin Juli 2017 (a) site 1 (b) site 2 (c) site 3 (d) site 4

\subsection{Analisis Angin Crosswind bulan Juli}

Dari hasil perhitungan menggunakan formula diperoleh hasil bahwa pada Juli 2017 potensi angin crosswind $>10 \mathrm{knot}$, terjadi satu kali di site 1 . Hasil perhitungan dapat dilihat pada Tabel 6.

Tabel 6a. Perhitungan Crosswind dan Tailwind Site 1

\begin{tabular}{llllll}
\hline Tgl & Jam & WS & WD & XW & HW/TW \\
\hline 6 & 08.51 & 18.7 & 140.4 & 9.5 & 16.1 \\
13 & 08.41 & 18.9 & 139.2 & 9.2 & 16.5 \\
24 & 09.29 & 18.7 & 142.5 & 10.0 & 15.8 \\
\hline
\end{tabular}

Tabel 6c. Perhitungan Crosswind dan Tailwind Site 3

\begin{tabular}{llllll}
\hline Tgl & Jam & WS & WD & XW & HW/TW \\
\hline 3 & 04.08 & 11.1 & 131.7 & 4.1 & 10.3 \\
13 & 09.12 & 11.1 & 131.7 & 4.1 & 10.3 \\
13 & 09.19 & 10.2 & 147.1 & 6.2 & 8.1 \\
\hline
\end{tabular}

Tabel 6b. Perhitungan Crosswind dan Tailwind Site 2

\begin{tabular}{llllll}
\hline Tgl & Jam & WS & WD & XW & HW/TW \\
\hline 13 & 09.11 & 19.9 & 132.1 & 7.5 & 18.4 \\
24 & 08.20 & 18.8 & 140.5 & 9.5 & 16.2 \\
\hline
\end{tabular}

Tabel 6d. Perhitungan Crosswind dan Tailwind Site 4

\begin{tabular}{llllll}
\hline Tgl & Jam & WS & WD & XW & HW/TW \\
\hline 13 & 09.47 & 12.7 & 132.5 & 4.9 & 11.7 \\
15 & 08.10 & 13.2 & 131.8 & 4.9 & 12.3 \\
24 & 09.22 & 12.8 & 141.2 & 6.6 & 10.9 \\
\hline
\end{tabular}

\subsection{Analisis Windrose bulan Agustus}

Pada bulan ini, angin muson timur masih kuat berpengaruh. Hal ini ditandai dengan arah angin bulan Agustus 2017 masih didominasi oleh angin dari Tenggara. Pada site 1 dan 2, kecepatan angina 10-13 knot sekitar $2 \%$, kecepatan angin 7-10 knot sekitar $6 \%$. Pada site 3, pada umumnya kecepatan angina 4-7 knot sekitar 8\%. Pada site4, kecepatan angin 7-10 knot sekitar 6\% dan kecepatan angina 4-7 knot juga sekitar $6 \%$. Kecepatan angin rata-rata berkisar 3 hingga 5 Knot dengan presentase angin calm sekitar 9\% (site 1, 2, dan 3) sedangkan presentase angin calm terendah tercatat di site 4 (2\%). Grafik windrose bulan Agustus 2017 dapat dilihat pada Gambar 7. 


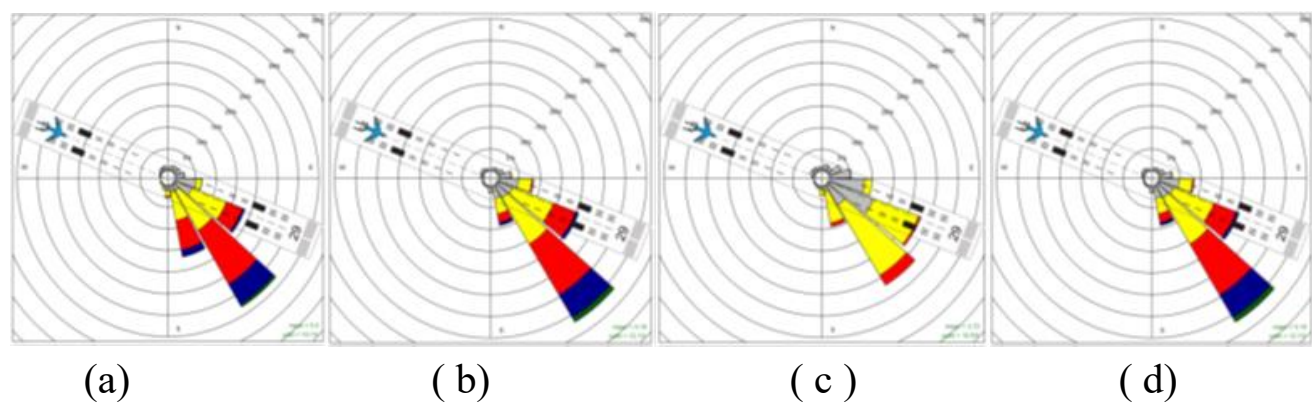

Gambar 7. Grafik Windrose Angin Agustus 2017 (a) site 1 (b) site 2 (c) site 3 (d) site 4

\subsection{Analisis Angin Crosswind bulan Agustus}

Dari hasil perhitungan menggunakan formula diperoleh hasil bahwa pada Agustus 2017 potensi angin crosswind $>10$ knot, terjadi di site 1 dan 2 . Hasil perhitungan dapat dilihat pada Tabel 7.

Tabel 7a. Perhitungan Crosswind dan Tailwind Site 1

\begin{tabular}{llllll}
\hline Tgl & Jam & WS & WD & XW & HW/TW \\
\hline 28 & 04.13 & 17 & 140.2 & 8.7 & 14.9 \\
28 & 04.22 & 17 & 147.2 & 10.5 & 13.8 \\
28 & 04.25 & 18 & 148.4 & 10.9 & 13.7 \\
\hline
\end{tabular}

Tabel 7c. Perhitungan Crosswind dan Tailwind Site 3

\begin{tabular}{llllll}
\hline Tgl & Jam & WS & WD & XW & HW/TW \\
\hline 28 & 08.05 & 9.9 & 146.9 & 5.9 & 7.9 \\
29 & 06.06 & 9.9 & 158.4 & 7.4 & 6.6 \\
\hline
\end{tabular}

Tabel 7b. Perhitungan Crosswind dan Tailwind Site 2

\begin{tabular}{llllll}
\hline Tgl & Jam & WS & WD & XW & HW/TW \\
\hline 28 & 06.29 & 19 & 147.8 & 11.9 & 15.3 \\
28 & 06.33 & 18 & 146 & 10.7 & 14.7 \\
28 & 07.00 & 19 & 142.6 & 10.1 & 15.8 \\
28 & 07.19 & 18 & 146.1 & 10.8 & 14.9 \\
\hline
\end{tabular}

Tabel 7d. Perhitungan Crosswind dan Tailwind Site 4

\begin{tabular}{llllll}
\hline Tgl & Jam & WS & WD & XW & HW/TW \\
\hline 28 & 06.15 & 12 & 139.7 & 6.1 & 10.7 \\
28 & 07.53 & 12 & 137.4 & 5.6 & 10.8 \\
\hline
\end{tabular}

\subsection{Analisis Windrose bulan September}

Arah angin di akhir periode pengamatan (September 2017) tetap didominasi oleh angin dari Tenggara yang merupakan ciri angin muson timur. Pada Site 1, kecepatan angina 10-13 knot sekitar $2 \%$, kecepatan angina 7-10 knot sekitar 6-8 \%. Di site 2, kecepatan angina 7-10 knot sekitar 6-8 \%, kecepatan angina 4-7 knot sekitar $6 \%$. Disite 3, kecepatan angina hanya mencapai 4-7 knot. Di site4, pada umumnya kecepatan angina 7-10 knot sekitar $8 \%$ dan kecepatan 4-7 knot sekitar $6 \%$. Grafik windrose bulan September 2017 dapat dilihat pada Gambar 8. 


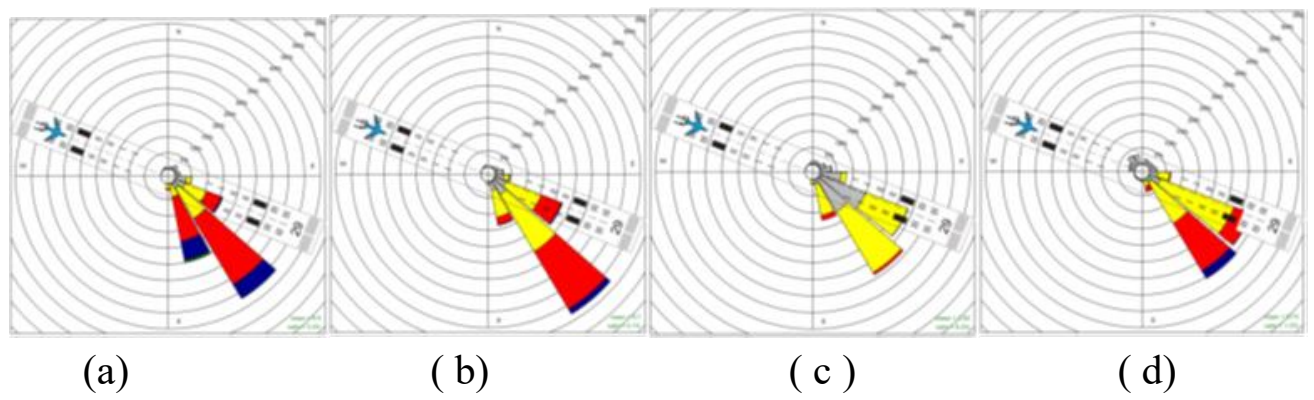

Gambar 8. Grafik Windrose Angin September 2017 (a) site 1 (b) site 2 (c) site 3 (d) site 4

\subsection{Analisis Angin Crosswind bulan September}

Dari hasil perhitungan menggunakan formula diperoleh hasil bahwa pada September 2017 potensi angin crosswind $>10 \mathrm{knot}$, hanya terjadi di site 1 . Hasil perhitungan dapat dilihat pada Tabel 8.

Tabel 8a. Perhitungan Crosswind dan Tailwind Site 1

\begin{tabular}{llllll}
\hline Tgl & Jam & WS & WD & XW & HW/TW \\
\hline 3 & 04.16 & 16 & 157 & 11.5 & 10.6 \\
3 & 04.26 & 16 & 156 & 11.3 & 10.8 \\
3 & 04.53 & 16 & 157 & 11.7 & 11.0 \\
3 & 05.23 & 16 & 156 & 11.1 & 10.9 \\
\hline
\end{tabular}

Tabel 8c. Perhitungan Crosswind dan tailwind Site 3

\begin{tabular}{llllll}
\hline Tgl & Jam & WS & WD & XW & HW/TW \\
\hline 2 & 05.23 & 8.8 & 161 & 6.8 & 5.5 \\
3 & 06.52 & 9.3 & 165 & 7.6 & 5.4 \\
\hline
\end{tabular}

Tabel 8b. Perhitungan Crosswind dan Tailwind Site 2

\begin{tabular}{llllll}
\hline Tgl & Jam & WS & WD & XW & HW/TW \\
\hline 3 & 03.04 & 12 & 143 & 6.7 & 10.4 \\
3 & 03.40 & 12 & 145 & 7.1 & 10.1 \\
3 & 03.55 & 13 & 145 & 7.3 & 10.6 \\
\hline
\end{tabular}

Tabel 8d. Perhitungan Crosswind dan Tailwind Site 4

\begin{tabular}{llllll}
\hline Tgl & Jam & WS & WD & XW & HW/TW \\
\hline 2 & 19.08 & 12 & 140 & 6.1 & 10.7 \\
2 & 20.46 & 12 & 137 & 5.6 & 10.8 \\
\hline
\end{tabular}

Hasil analisis bulanan menunjukan bahwa angin muson barat berpengaruh pada pengamatan bulan maret. Sedangkan pada bulan April, arah angin bervariasi yang menunjukan adanya musim transisi yang kuat pada bulan tersebut. Sedangkan pada bulan Mei hingga September, angin muson timur sangat berpengaruh selama periode pengamatan. Hal ini disebabkan karena iklim di Indonesia terutama Jawa sangat dipengaruhi oleh angin Muson (Robertson, 2010).

\section{KESIMPULAN}

Pola angin pada periode Maret - Mei memiliki arah yang bervariasi dengan kecepatan ratarata $5-8$ knot. Pada periode Juni - September, pola angin berhembus dari arah Timur Tenggara dengan kecepatan rata-rata 6 - 9 knot. Selama periode pengamatan kecepatan angin maksimum yang terjadi antara $14-20$ knot.

Berdasarkan hasil analisis potensi terjadinya cross wind, bahwa untuk pengembangan panjang runway hingga mencapai 3600 meter, dapat disimpulkan tidak ada potensi terjadi nya cross wind. 


\section{UCAPAN TERIMAKASIH}

Penulis mengucapkan Terima kasih kepada Tim Survey Pengamatan Cuaca Badan Meteorologi Klimatologi dan Geofisika (BMKG) serta PT. Angkasa Pura 1 atas data hasil observasi yang kami pakai.

\section{DAFTAR PUSTAKA}

Bellasio, R. (2014). Analysis of wind data for airport runway design. Journal of Airline and Airport management. JAIRM, 2014 - 4(2), 97-116.

Boeing. (1999). Boeing 737 Limitation. Di akses $21 \quad$ Februari 2019 dari http://www.b737.org.uk/limitations.htm

Cashman, J. (2014). Crosswind Guidelines. The Boeing Company. [PDF document]. Di Akses 17 Februari 2019 dari http://docslide.us/documents/crosswind-guidelines1.html

FAA. (2000). Appendix 1, Wind Analysis. Adisory Circular. AC 150/5300-13 CHG 6. Washington, DC. United States. 2000.

FAA. (2014). Allowable crosswind component per Runway Design Code in knots $(\mathrm{m} / \mathrm{s}$ in parenthesis). http://www.faa.gov/airports/engineering/design_standards/ - di Akses 19 Februari 2019

Fadholi, A. (2012). Analisa Pola Angin Permukaan di Bandar Udara Depati Amir Pangkalpinang Periode Januari 2000 - Desember 2012. Jurnal Statistika Universitas Islam Bandung. Vol. 12 No. 1 Mei, 2012.Fadholi, A. (2013). Analisis Komponen Angin Landas Pacu (Runway) Bandara Depati Amir Pangkalpinang. Jurnal Statistika, Vol. 13 No. 2, 45 - 53, 2013.

Gerz, T. (2013). Mitigating the impact of weather hazards on aviation. WWOSC 2014, Montreal, Canada.

Hahn, K. U (1989). Effect of Wind Shear on Flight Safety. Prog. Aerospace Sci. Voi. 26, pp. 225-259, 1989

ICAO. (2011). Aerodrome Meteorological Observation and Forecast Study Group (AMOFSG), Ninth Meeting, 26 to 30 September 2011, Montreal, Canada, 2011.

ICAO. (2009). Aerodrome Design and Operation. Annex 14 to the Convention on International Civil Aviation. Fifth Edition, July 2009.

Keputusan Menteri Perhubungan. (2013). Penetapan Lokasi Bandar Udara Baru di Kabupaten Kulon Progo Provinsi Daerah Istimewa Yogyakarta. KepMenhub No. KP 1164 Th 2013.

Page, C. (2010). Understanding Aviation Meteorology and Weather Hazards with GroundBased Observations. In book: Integrated Ground-Based Observing Systems, January 2010.

Robertson, A. W., V. Moron, J.-H. Qian, C.-P. Chang, F. Tangang, E. Aldrian, T. Y. Koh, and L. Juneng. (2010). The Maritime Continent monsoon. The Global Monsoon System: Research and Forecast, 2nd ed.

Tjasyono, B.H.K. (2004). Klimatologi. ITB, Bandung.

Van Es, G.W.H and A.K. Karwal. (2011). Safety aspects of tailwind operationsSafety aspects of tailwind operations Safety aspects of tailwind operations. National Aerospace Laboratory-NLR. NLR-TP-2001-003

WMO (2008). Measurement of meteorological Variable. World Meteorological Organization, 2008.

WRPLOT. (2016). WRPLOT View User Guide. Lakes Environmental Software, Canada. 